\title{
Learning During the Covid-19 Pandemic: Correlation Between Income Levels And Parental Roles
}

\author{
Kartika Rinakit Adhe ${ }^{\circledR}$, Rohmatul Maulidiya ${ }^{2}$, Muchamad Arif Al Ardha ${ }^{3}$, Wulan Patria \\ Saroinsong ${ }^{4}$, Sri Widayati ${ }^{5}$ \\ Pendidikan Guru Pendidikan Anak Usia Dini, Universitas Negeri Surabaya $(1,2,4,5)$ \\ Pendidikan Olahraga, Universitas Negeri Surabaya ${ }^{(3)}$ \\ DOI: $\underline{10.31004 / \text { obsesi.v5i1.554 }}$
}

\begin{abstract}
This study aims to determine the correlation between parental income levels with the role of parents. The sample is 370 parents of affected by Covid-19 pandemic in Indonesia. The method used is a quantitative correlational approach to the type of survey analysis. The results showed the frequency of parents playing with children before and during the pandemic increased from $38.6 \%$ to $62.0 \%$. The results of the bivariate correlation analysis are significance values of 9,956 (Sig> 0.05) with Pearson correlation coefficient numbers showing a result of -0.003 which means that the correlation only 0.003 . The correlation coefficient is negative then correlation is inversely proportional, if the income level is moderate then the role of parents is high and vice versa which means that $\mathrm{Ha}$ is rejected and Ho is accepted there is no correlation between the level of parental income with the role of parents in early childhood learning during Covid-19.
\end{abstract}

Keywords: covid-19 pandemic; parent income level; parents' roles

\begin{abstract}
Penelitian ini bertujuan untuk mengetahui hubungan antara tingkat pendapatan orang tua dengan peran orang tua. Sampel adalah 370 orang tua yang terkena pandemi Covid-19 di Indonesia. Metode yang digunakan adalah pendekatan korelasional kuantitatif dengan jenis analisis survei. Hasil penelitian menunjukkan frekuensi orang tua bermain dengan anak-anak sebelum dan selama pandemi meningkat dari 38,6\% menjadi 62,0\%. Hasil analisis korelasi bivariat adalah nilai signifikansi 9,956 (Sig> 0,05) dengan angka koefisien korelasi Pearson menunjukkan hasil $-0,003$ yang berarti bahwa korelasinya hanya 0,003. Koefisien korelasi negatif maka korelasi berbanding terbalik, jika tingkat pendapatan sedang maka peran orang tua tinggi dan sebaliknya yang berarti Ha ditolak dan Ho diterima tidak ada korelasi antara tingkat pendapatan orang tua dengan peran orang tua dalam pembelajaran anak usia dini selama Covid-19.
\end{abstract}

Keywords: pandemi covid-19; tingkat pendapatan orang tua; peran orang tua

Copyright (c) 2020 Kartika Rinakit Adhe, Rohmatul Maulidiya, Muchamad Arif Al Ardha, Wulan Patria Saroinsong, Sri Widayati

$\triangle$ Corresponding author:

Email Address : kartikaadhe@unesa.ac.id ( Surabaya, Indonesia )

Received 26 May 2020, Accepted 2 June 2020, Published 8 June 2020 


\section{INTRODUCTION}

Education in early childhood is very important and must be done since the child was born (Fadillah, 2020). Related to this the role of parents is needed in early childhood education. A role is a set of interpersonal behaviors, traits, activities related to the person in certain positions and, situations (Hind et al., 2019). The family is the first and foremost place for children to get an education, this process requires an important role from parents (Lo Cricchio et al., 2019). Regarding those ideas, it can be concluded that education in early childhood is the prority and started since the child was born. Therefore the role of parents is necessary to shape a good personality and its development process.

Parents are men and women who are bound in marriage and are ready to assume the responsibilities of being the father and mother of the children they are born with. Meanwhile, parents are two different individuals who enter life together by bringing views and daily habits (Hidayah et al., 2019). Parents as each person who is responsible for a family or household chores which in daily life are called father and mother (van Nunen et al., 2015). Based on the explanation above, it can be concluded that the role of parents is behavior related to parents in holding certain positions in family institutions in which function as caregivers, guides and educators for children (Yadav \& Chandola, 2019).

Indonesia is one of hundreds of countries in the world affected by Covid-19. This pandemic has an impact on the educational process, economic, social, tourism, etc. The spread of the COVID-19 virus is very fast, the main target is the community aged $>60$ years and early childhood, it occurs due to a decline in the immune system in people aged $>60$ years and the incomplete immune system that is formed in early childhood (WHO, 2020). But the problem now is that many parents' income is decreasing and many are losing their jobs, so what about their role in children's learning? Under normal circumstances before the economic level of the Covid-19 pandemic parents stabilized. Parents can pay school fees for children, can provide school facilities, in addition they pay for extracurricular activities at school. But the current situation is far different. One effect of this problem is parents who become unemployed.

The economic level of parents is the economic ability of parents to meet every living needs of family members (Awan, Masood Sarwar and Malik \& Haroon and Waqas, 2011). Parents who have a high economic level will certainly provide all the facilities and infrastructure to support their children's education, while parents who have a low economic level will certainly pay less attention to their children's learning facilities (Mallick et al., 2016). It is assumed that the low economic level of parents will experience difficulties in fulfilling the suggestions and learning infrastructure available at home such as lighting conditions, study rooms, etc. The economic level of the family is closely related to children's learning, because children who are learning in addition to having to meet their basic needs, also need learning facilities that can be met if the economic level of parents is adequate (Breierova \& Duflo, 2004) (Wiseman \& Young, 2013).

In the Covid-19 pandemic, parents spend more time at home, so parents can play a bigger role in children's learning at home, because the role of parents in children's learning at home is very necessary (Praherdhiono \& Eka Pramono Adi, Yulias Prihatmoko, Nunung Nindigraha, Yerry Soepriyanto, Henny Indreswari, 2020) (Hewi \& Asnawati, 2020). Without the role of parents in children's learning activities at home it is impossible to improve optimal learning for children. Apart from the role of parents in providing encouragement motivation to children, guiding children in playing and learning, being a good role model, establishing smooth communication with children, observing and controlling what children do, recognizing children's difficulties in playing and learning and fulfilling and complete all the needs of children. Parents also made contact between teachers and children during this pandemic. During this pandemic can be a golden opportunity for parents to create more perfect attachment to children (Cesur et al., 2014). 
Parents can teach their children something that children don't get at school, which is about life skills (Hewi \& Asnawati, 2020). This can be done by inviting children to make their beds, make toys or learn independently, get to know themselves, express their feelings, grow their entrepreneurial spirit early on and so on. For early childhood, the role of parents is always needed. However, it is found that the role of parents is influenced by the economic level. If the economic level of parents is high then the role of parents to children will be more maximal and if the economic level of parents is low then the role of parents to children will be less or less. During the Covid-19 pandemic, the average parent experienced a decline in the economic level.

Pandemic means an outbreak of a disease that attacks many victims, simultaneously in various countries. This disease has affected many countries in the world, one of them is Indonesia. In early March Indonesia recorded its first positive case. Two people reported positive about Covid-19 in Jakarta. The government has also taken steps to anticipate the further spread of this virus by doing lockdown since March 2020 by WHO. This situation causes workers to become Work From Home even layoff. Based on data from the Ministry of Manpower as of April 20, 2020, there were 2,084,593 workers from 116,370 companies laidoff due to the corona pandemic. As for the details, the formal sector 1,304,777 workers were laid-off from 43,690 companies. While those affected by layoffs reached 241,431 people from 41,236 companies.

The informal sector was also hit by the loss of 538,385 workers affected from 31,444 companies. The impact of the Corona Pandemic has resulted in a decrease in the current economic level, so what is the role of parents in early childhood learning with uncertain economic conditions? Therefore, it is deemed necessary to conduct a study with the title "The Role of Parents in Early Childhood Learning in the Covid-19 Period". So the purpose of this study is to determine whether there is a correlation between the level of income of parents in their role in learning during the pandemic. This is intended to provide information on public concerns about the high level of unemployment or the decline in parental income and also this has an impact on parents undergoing their role. This research solely taken during the covid-19 pandemic, due to the large number of people or parents experiencing economic decline and jobless those were the livelihoods of parents. It is intended to find out whether the level of economic decline of parents has an impact on children's learning during the covid-19 pandemic.

\section{METHODOLOGY}

The approach used in this study is a quantitative approach to the type of survey analysis. Correlational survey research is research that really only describes what is or occurs in a particular scene, field or region to find out the level of correlation between two or more variables, without making changes, additions or manipulation of existing data (Walliman, 2017). This study has two variables, namely the dependent variable (Y) the Role of Parents and the independent variable $(X)$ Parental Income. The population in this study were parents of children aged 4-6 years affected by the Covid-19 pandemic in Java Indonesia. The sample was 370 parents of preschool children aged 4-6 years in Indonesia who were affected by the Covid-19 pandemic. The sampling technique used in this study is the cluster sampling technique. 


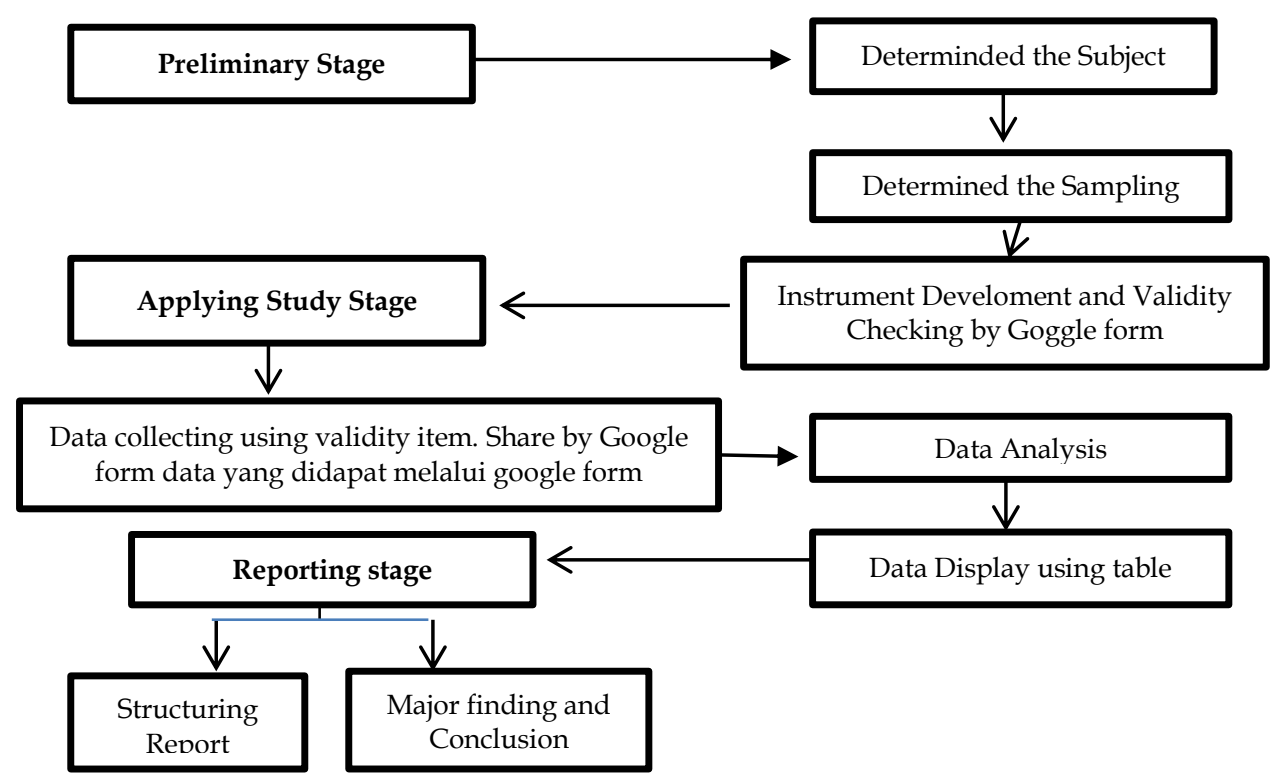

Picture 1 The Study Procedure

Data collection techniques by distributing questionnaires with closed questionnaires (Walliman, 2017). This questionnaire using Likert scale through online surveys with answers including the Strongly Agree (SA), Agree (A), Undecided (U), Disagree (D), Strongly Disagree (SD). To give a score, the answer is given a score value or weight where for favorable items (SA) are given a score of 5, (A) score 4, (U) score 3, (D) score 2, (SD) score 1 and vice versa for unfavorable items. The instrument validity and reliability tests use the product-moment formula to calculate validity and Cronbach's Alpha to calculate reliability (Cohen et al., 2003).

Analysis of the data in this study used the Statistical Package for the Social Sciences (SPSS) program with type 25.00 analysis techniques in this study, namely the data analysis using bivariate correlation analysis. with the normality test and hypothesis as a prerequisite test. The normality test uses Kolmogorov-Smirnov. The rule used is if the sig value $>0.05$ then the distribution is normal, conversely if the distribution of sig value $\leq 0.05$ then the distribution is not normal. While testing the hypothesis using simple correlation analysis (Cohen et al., 2003).

\section{RESULT AND DISCUSSION}

Based on the data collected, the following is part of a Google form that has been deployed to get the results of research will be outlined below:

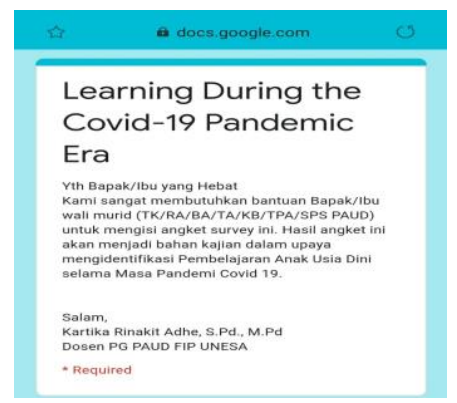

Gambar 2 Image of online survey research

Link google form attcahed

https://forms.gle/gWJv22Sg5VYYbrkS9 
Learning During the Covid-19 Pandemic: Correlation Between Income Levels And Parental Roles DOI: $10.31004 /$ obsesi.v5i1.554

\section{General data}

General data includes the characteristics of respondents based on gender, age, education, and occupation.

Table 1 Characteristics of Respondents by Gender of Parents in Indonesia

\begin{tabular}{lll}
\hline Gender & Frequency & \multicolumn{1}{c}{$\%$} \\
\hline Female & 329 & 89,4 \\
\hline Male & 39 & 10,6 \\
\hline Total & $\mathbf{3 6 8}$ & $\mathbf{1 0 0 , 0}$ \\
\hline
\end{tabular}

Based on table 1 shows that more than $50 \%$ of respondents from 370 parents of young children affected by Covid-19 in Indonesia were female, namely 329 respondents $(89.4 \%)$ and 39 male respondents $(10, \%)$

Table 2 Characteristics of Respondents by Age of Parents in Indonesia

\begin{tabular}{lll}
\hline Age & Frequency & $\mathbf{\%}$ \\
\hline$<\mathbf{2 0}$ years & 3 & 8 \\
\hline $\mathbf{2 1}-\mathbf{2 5}$ years & 20 & 5,4 \\
\hline $\mathbf{2 6}-\mathbf{3 0}$ years & 97 & 26,4 \\
\hline $\mathbf{3 1}-\mathbf{3 5}$ years & 115 & 31,3 \\
\hline$>\mathbf{3 6}$ years & 133 & 36,1 \\
\hline Total & $\mathbf{3 6 8}$ & $\mathbf{1 0 0 , 0}$ \\
\hline
\end{tabular}

Based on table 2 shows that more than $50 \%$ of the respondents of 370 parents of young children affected by Covid-19 in Indonesia aged $\geq 36$ years were 133 respondents (36.1\%), then aged 31-35 years 155 respondents (31, 3\%), 26-30 years 97 respondents $(26.4 \%)$ and aged $<20$ years 3 respondents $(8 \%)$. Based on table 2 shows that more than $50 \%$ of the respondents of 370 parents of young children affected by Covid-19 in Indonesia aged $\geq 36$ years were 133 respondents (36.1\%), then aged 31-35 years 155 respondents (31, 3\%), 26-30 years 97 respondents $(26.4 \%)$ and aged $<20$ years 3 respondents $(8 \%)$. Based on research conducted by the University of California that being a parent in old age has more advantages than disadvantages. But when asked about the optimal age to have children, $80 \%$ of women and $70 \%$ of men answered in their 30s. Most of them claimed that it was the situation that prevented them from being able to have children at the age of 30 years. However, from one to third of women and a quarter of men in the study said the disadvantage of being a parent when old age is reduced physical strength. In the above results, there is no significant comparison between the old age and the easy age of 370 parents affected by Covid-19 in Indonesia.

Table 3 Characteristics of Respondents Based on Parents' Work

\begin{tabular}{lll}
\hline profession & Frequency & \% \\
\hline housewife & 214 & 58,2 \\
\hline Pensioners & 1 &, 3 \\
\hline Civil servants & 7 & 1,9 \\
\hline Teacher & 40 & 10,9 \\
\hline Lecturer & 8 & 2,2 \\
\hline National Army & 1 &, 3 \\
\hline Others & 96 & 26,1 \\
\hline Total & $\mathbf{3 6 8}$ & $\mathbf{1 0 0 , 0}$ \\
\hline
\end{tabular}


Based on table 4 that the respondents of 370 parents of young children affected by Covid-19 in Indonesia have a job as a housewife as many as 214 respondents (58.2\%), others are not known 98 respondents (26\%), teachers 40 respondents $(10.9 \%)$, lecturers 8 respondents (2\%), civil servants 7 respondents, Pensioners and National Army 1 respondent $(3 \%)$.

Table 4 Characteristics of Respondents Based on WFH Status

\begin{tabular}{lcl}
\hline & Frequency & \% \\
\hline Non & 124 & 33,7 \\
WFH & & \\
\hline WFH & 244 & 66,3 \\
\hline Total & $\mathbf{3 6 8}$ & $\mathbf{1 0 0 , 0}$ \\
\hline
\end{tabular}

Based on table 5 shows that more than $50 \%$ of respondents from 370 parents of young children affected by Covid-19 in Indonesia who are WFH are 244 respondents $(66.3 \%)$ and 124 respondents $(33.7 \%)$ are non WFH status.

Table 5 Characteristics of Respondents' Income Levels

\begin{tabular}{lcc}
\hline Income & Frequency & \% \\
\hline$\leq \operatorname{Rp~} 1.500 .000$ & 127 & 34,5 \\
\hline $\operatorname{Rp~} 1.500 .000-\operatorname{Rp} .2 .500 .000$ & 88 & 23,9 \\
\hline $\operatorname{Rp~2.500.000-Rp~3.500.000~}$ & 76 & 20,7 \\
\hline$\geq \operatorname{Rp~3.500.000~}$ & 77 & 20,9 \\
\hline Total & $\mathbf{3 6 8}$ & $\mathbf{1 0 0 , 0}$ \\
\hline
\end{tabular}

Based on table 6 that the respondents of 370 parents of young children affected by Covid-19 in Indonesia are 127 respondents (34.5\%) earning $\leq R p$ 1,500,000, 88 respondents (23.9\%) earning $R p$ 1,500,000 - Rp . 2,500,000, 77 respondents earn $3.5 \mathrm{Rp} 3,500,000$. The income earned by parents per month.

Table 6 Frequency of Parents with Children Before Pandemic

\begin{tabular}{lcl}
\hline Before Pandemic & Frequency & \% \\
\hline$\leq 1$ hour & 66 & 17,8 \\
\hline$\leq 1$ hour 30 minutes & 74 & 20,0 \\
\hline 1 hour 30 minute -2 hours & 88 & 23,8 \\
\hline$>$ 2 hours & 142 & 38,4 \\
\hline Total & $\mathbf{3 7 0}$ & $\mathbf{1 0 0 , 0}$ \\
\hline
\end{tabular}

Based on table 7 shows that more than $50 \%$ of the 370 respondents who have a frequency of time> 2 hours $(38 \%)$, with children, 1 hour 30 minutes - 2 hours $(23.8 \%), \leq 1$ hour $(17.8 \%)$ and $\leq 1$ hour 30 minutes $(20.0 \%)$.

Table 7 Frequency of Parents with Children During Pandemic

\begin{tabular}{lll}
\hline After Pandemic & Frequency & $\%$ \\
\hline$\leq 1$ hour & 15 & 4,1 \\
\hline$\leq 1$ hour 30 minutes & 44 & 12,0 \\
\hline 1 hour 30 minutes -2 hours & 175 & 47,6 \\
\hline$>2$ hours & 110 & 29,9 \\
\hline Total & 368 & 100,0 \\
\hline
\end{tabular}


Based on table 8 shows that more than $50 \%$ of the 370 respondents who have a frequency of time> 2 hours $(62 \%)$, with children, 1 hour 30 minutes -2 hours $(17.8 \%), \leq 1$ hour $(12.7 \%)$ and $\leq 1$ hour 30 minutes $(7.0 \%)$.

\section{Normality Test}

Table 8 Normality Test Results

\begin{tabular}{l|l}
\hline & Kolmogorov-Smirnov \\
\hline Parents Income & 0,200 \\
the role of parents & 0,200 \\
\hline
\end{tabular}

Residual values can be said to be normal if Sig> a. Based on the results in table 6 shows that of the two variables have a Significance value $(0.200)$ which means Sig> a so that the residual value is normally distributed.

\section{Hypothesis test}

The hypothesis that researchers obtained is as follows:

$\mathrm{Ha}$ : There is a correlation between parental income and the role of parents in early childhood learning during the Covid-19 pandemic.

$\mathrm{H}_{\mathrm{o}} \quad$ : There is no correlation between parental income and the role of parents in early childhood learning during the Covid-19 pandemic.

Ho $: \rho=0,0$ There is no correlation

Ha $: \rho \neq 0$, "Not equal to zero" means greater or less (-) than zero means there is a correlation.

\section{Bivariate Correlation Analysis}

From the table above shows the significance of Sig. 0.956 so it can be stated that the income level variable has no correlation with the role of parents because 0.0956>0.05. For Pearson correlation coefficient numbers show results of -0.003 .

Table 9 Correlation Test Results

\begin{tabular}{llcc}
\hline & Income level & $\begin{array}{l}\text { The role of } \\
\text { parents }\end{array}$ \\
\hline \multirow{3}{*}{ Income Level } & Pearson Correlation & 1 &,- 003 \\
& Sig. (2-tailed) & &, 956 \\
\multirow{5}{*}{ The Role of Parents } & 370 & 370 \\
& N &,- 003 & 1 \\
& Pearson Correlation &, 956 & \\
& Sig. (2-tailed) & 370 & 370 \\
\hline
\end{tabular}

\section{Discussion}

Based on research conducted by distributing online questionnaires with 370 respondents of early childhood parents who were affected by the Covid-19 pandemic in Indonesia produced data that had been analyzed with bivariate correlation analysis that the role of parents had no correlation with the level of income of parents with a significance value of 9,956 ( Sig> 0.05) with Pearson correlation coefficient figures show a result of -0.003 which means that the correlation is very low only 0.003 . The correlation coefficient is negative, then the correlation is inversely proportional, if the income level is moderate, the role of parents is high and vice versa. 
It can be explained that the level of income of parents does not have a correlation with the role of parents, even though parents have a low-income level parents can still play a role even have to continue to play a role in early childhood learning, because learning in childhood does not only require material or facilities to learn such as desks, lighting, books, games and others but also requires love through guidance, direction, motivation, care for young children who do not need a number of materials to fulfill this. Even for a game, parents can make use of materials that are around or with traditional games (Hewi \& Asnawati, 2020).

During the Covid-19 pandemic, most parents experienced a decrease in their income, but on the other hand the Covid-19 pandemic increased the amount of time parents spent at home with children. With this it can be an opportunity for parents to maximize their role as parents of children. According to theory, role is a form of real behavior (Toscano et al., 2020). So what is needed more by early childhood is the real behavior of parents, not the material (Lo Cricchio et al., 2019). One of the important things to develop early is about life skills.

Based on research results from the answers of 370 parents of young children affected by Covid-19 in Indonesia that while at home during the pandemic, besides assisting children in learning or assignments from teachers, parents also develop children's life skills (Junge et al., 2003). Life skills education in early childhood is education that provides personal skills, social skills, intellectual skills and vocational skills to try or live independently (Fahmie \& Luczynski, 2018). The four components of skills are very important to apply early by pursuing children to time management, self-defense, cleaning the house, managing money, (piggy bank, allowance, kindness rewards), cleaning toys, cleaning beds and so forth (Maleki et al., 2019). This can be developed by parents, both father and mother, well and successfully even though parents have low-income.

Theoretically, the role is the concept of what individuals can do in society as an organization, the role can also be interpreted as a behavior of individuals who are important for the social structure of society (Hind et al., 2019). Role is a form of real behavior . The role of parents is something that is expected of children from fathers and mothers in certain situations according to the function, potential, ability, and responsibility in order to meet expectations .The role of parents in general, includes the role of fathers and the role of mothers. The role of the father is a family leader who has a role as a breadwinner, educator, protector or protector, a provider of security for each family member and also as members of a particular social group community. While the role of the mother is as a housekeeper, caregiver and child educator, family protector and also as a breadwinner for the family and as members of the community certain social groups.

Based on the results of data analysis that out of 370 parents of children affected by Covid-19 in Indonesia have downstream income 127 respondents $(34.5 \%)$ parents who earn $\leq$ Rp 1,500,000, 88 respondents (23.9\%) people parents who earn $\operatorname{Rp~1,500,000~-~Rp.~2,500,000,~}$ 77 elderly respondents with $\operatorname{Rp} 3,000,000-5,500,000$. The following is data besed on the income result which is the income obtained by parents per month. It is revelaed that, the parent financial has decrase during pandemic Covid -19 .

Based on the classification, the Central Bureau of Statistics differentiates the income of the population into four categories, namely: 1) The very high income group is if the average income is more than Rp. 3,500,000.00 per month. 2) The high income group is if the average income is between Rp. 2,500,000.00 to Rp. 3,500,000.00 per month. 3) Medium income is if the average income is below Rp. 1,500,000.00 to Rp. 2,500,000.00 per month. 4) The income group is low if the average income is Rp. 1,500,000.00 per month.

Based on the results of the study, parents of young children affected by Covid-19 in Indonesia continue to play their role as parents. Evidenced by the results of the analysis of the frequency of respondents with children before and during the Covid-19 pandemic. Before the Covid-19 pandemic more than $50 \%$ of respondents from 370 people had a frequency of more than 2 hours (38\%) and when the pandemic Covid-19 the frequency increased to $(62.0 \%)$ 
which means that parents spend more time with children during the Covid-19 pandemic compared to before the Covid-19 pandemic. With positive answers from respondents where they continue to play their role as parents, that is, parents provide motivation to children, parents guide children in playing and learning, parents become good role models, parents establish smooth communication with children, parents observe and control what children do, parents recognize the difficulties of children in playing and learning, parents meet and complete all the needs of children

Parental income is the parent's income in the form of money received as compensation from both formal and informal sector activities for one month. The size of the income received by each population will differ from one another, this is because it is influenced by the situation of the population itself in carrying out various kinds of daily activities (Wiseman \& Young, 2013). Income received by households will be used to buy food, buy clothes, finance transportation services, pay for children's education and others.

This shows the research findings that public fear about the number of parents stopping work will affect daily life. But this is not found when parents carry out their daily roles in accompanying their children. Parents still do what parents should do to support children's growth and development.

\section{CONCLUSION}

Based on the research conducted, it can be concluded that the results of the bivariate correlational $0.0956>0.05$ with a Pearson correlation coefficient is very low only 0.003 . The correlation coefficient is negative, then the correlation is inversely proportional. There is no correlation between the level of income of parents with the role of parents. Moreover,this studycan be suggest to Parents for maximizing their role on early childhood concern during the Covid-19 pandemic. Furthermore, Parents should pay attention for the quality time to engage with heir children. Besides, The next study, expected to make this research as a reference for conducting relevant research.

\section{ACKNOWLEDGEMENT}

First of all, the gratitude going to Unesa that has contribute to this study. Moreover to all the parent in indonesia those were participated.

\section{REFERENCE}

Awan, Masood Sarwar and Malik, N. and S., \& Haroon and Waqas, M. (2011). Impact of education on poverty reduction. Munich Personal RePEc Archive.

Breierova, L., \& Duflo, E. (2004). The Impact of Education on Fertility and Child Mortality: Do Fathers Really Matter Less Than Mothers? https:/ / doi.org/10.3386/w10513

Cesur, R., Dursun, B., \& Mocan, N. (2014). The Impact of Education on Health and Health Behavior in a Middle-Income, Low-Education Country. https:// doi.org/10.3386/w20764

Cohen, J., Cohen, P., West, S. G. W., \& Aiken, L. S. (2003). Applied Multiple Regression/Correlation Analysis for the Behavioral Sciences. lawrence Erbaum Associate.

Fadillah, F. (2020). Early Childhood Metacognitive Learning among Students of Early Childhood Teacher Education. Jurnal Obsesi : Jurnal Pendidikan Anak Usia Dini, 4(2), 658-664.

Fahmie, T. A., \& Luczynski, K. C. (2018). Preschool life skills: Recent advancements and future directions. Journal of Applied Behavior Analysis, 51(1), 183-188. https://doi.org/10.1002/jaba.434

Hewi, L., \& Asnawati, L. (2020). Strategi Pendidik Anak Usia Dini Era Covid-19 dalam Menumbuhkan Kemampuan Berfikir Logis. Jurnal Obsesi : Jurnal Pendidikan Anak Usia Dini, 5(1), 158-167. https:/ / doi.org/10.31004/ obsesi.v5i1.530 
Hidayah, S. N., Yuniastuti, A., \& Kuswardinah, A. (2019). Difference of Maternal Parenting Style on Child's Growth And Motoric Development. Public Health Perspective Journal, $0(0)$.

Hind, K., Larkin, R., \& Dunn, A. K. (2019). Assessing Teacher Opinion on the Inclusion of Children with Social, Emotional and Behavioural Difficulties into Mainstream School Classes. International Journal of Disability, Development and Education, 66(4), 424-437. https:/ / doi.org/10.1080/1034912X.2018.1460462

Junge, S. K., Manglallan, S., \& Raskauskas, J. (2003). Building life skills through afterschool participation in experiential and cooperative learning. Child Study Journal, 33(3), 165175.

Lo Cricchio, M. G., Lo Coco, A., Cheah, C. S. L., \& Liga, F. (2019). The Good Parent: Southern Italian Mothers' Conceptualization of Good Parenting and Parent-Child Relationships. Journal of Family Issues, 40(12), 1583-1603. https:/ / doi.org/10.1177/0192513X19842598

Maleki, M., Chehrzad, M. M., Kazemnezhad Leyli, E., Mardani, A., \& Vaismoradi, M. (2019). Social Skills in Preschool Children from Teachers' Perspectives. Children, 6(5), 64. https:// doi.org/10.3390/children6050064

Mallick, L., Kumar, P., \& Pradhan, K. C. P. (2016). Impact of educational expenditure on economic growth in major Asian countries: Evidence from econometric analysis. Theoretical and Applied Economics, XXIII(2), 173-186.

Praherdhiono, H., \& Eka Pramono Adi, Yulias Prihatmoko, Nunung Nindigraha, Yerry Soepriyanto, Henny Indreswari, H. I. O. (2020). Implementasi Pembelajaran di Era dan Pasca Pandemi Covid-19 - Henry Praherdhiono, Eka Pramono Adi, Yulias Prihatmoko, Nunung Nindigraha, Yerry Soepriyanto, Henny Indreswari, Herlina Ike Oktaviani - Google Books. CV. Seribu Bintang.

Toscano, C., Soares, I., \& Mesman, J. (2020). Controlling Parenting Behaviors in Parents of Children Born Preterm. Journal of Developmental \& Behavioral Pediatrics, 41(3), 230-241. https:// doi.org/10.1097/DBP.0000000000000762

van Nunen, K., Kaerts, N., Wyndaele, J.-J., Vermandel, A., \& Hal, G. Van. (2015). Parents' views on toilet training (TT). Journal of Child Health Care, 19(2), 265-274. https:/ / doi.org/10.1177/1367493513508232

Walliman, N. (2017). Research Methods: The Basics. Routledge. https:// doi.org/10.4324/9781315529011

WHO. (2020). Coronavirus disease (COVID-19) outbreak. Emergencies - Diseases.

Wiseman, T., \& Young, A. T. (2013). Economic Freedom, Entrepreneurship, \&amp; Income Levels: Some Us State-Level Empirics Economic Freedom, Entrepreneurship, \&amp; Income Levels: Some Us State-Level Empirics. American Journal of Entrepreneurship, VI(1), 104-124.

Yadav, P. P. S., \& Chandola, R. (2019). Authoritarian Parenting Style And Its Effect on SelfEsteem And Coping Strategies Of 21 Year Old GirL. Global Journal For Research Analysis, 8(3). 